\title{
MUNCULNYA CULTURE SHOCK PADA MAHASISWA BARU DALAM PERKULIAHAN DARING SELAMA PANDEMI COVID-19
}

\author{
Arifah Munawaroh Chafsoh ${ }^{\left.\mathrm{a}^{*}\right)}$ \\ Mahasiswa Sarjana-S1 Program Studi Psikologi, Fakultas Kedokteran, Universitas Lambung \\ Mangkurat, Jalan Ahmad Yani Km 36, Banjarbaru, 70714, Indonesia \\ ${ }^{*}$ Penulis Korespondensi: arifaahmc@gmail.com \\ Sejarah artikel: diterima 18 November 2020; diterima 31 Desember 2020
}

\begin{abstract}
Abstrak. Culture Shock adalah kondisi seseorang merasa takut dan khawatir yang berlebihan ketika berada di lingkungan baru yang tidak terbiasa oleh dirinya. Kehidupan perkuliahan baru secara daring selama pandemi covid-19 ini membuat tak sedikit mahasiswa baru merasa tertekan dan gelisah mengenai apa yang harus dilakukannya di lingkungan barunya ini. Perkuliahan secara daring membuat mahasiswa baru mengalami kesulitan dalam beradaptasi sehingga memicu stres dari culture shock yang ia alami selama perkuliahan daring. Penelitian ini bertujuan untuk mendeskripsikan seberapa besar pengaruhnya perkuliahan daring selama pandemi covid-19 sehingga memunculkan gejala culture shock pada mahasiswa baru. Penelitian dilakukan menggunakan kajian literatur dan metode introspeksi diri oleh penulis. Hasil penelitian ini menunjukan adanya permasalahan psikologis individu yaitu culture shock sebagai mahasiswa baru dalam menjalani perkuliahan daring.
\end{abstract}

Kata kunci: Culture Shock; mahasiwa baru; perkuliahan daring

\section{PENDAHULUAN}

Pandemi Covid-19 yang masih terjadi di Indonesia membuat aktivitas kegiatan pendidikan di Indonesia ikut terkena dampaknya. Kegiatan pendidikan yang biasanya dilakukan di tempat secara langsung dengan tatap muka kini beralih ke pendidikan secara online atau daring (dalam jaringan) melalui aplikasi room online yang mempertemukan semua mahasiswa dalam kegiatan proses pendidikan berlangsung. Dunia baru perkuliahan daring ini, membuat interaksi menjadi serba terbatas, hanya mengandalkan room chat online sebagai interaksi antar sesama mahasiswa baru untuk saling mengenal dan berdiskusi.

Peran interaksi sosial secara langsung yang saling menghubungkan manusia, kini 
dunia telah memberi batas dalam berinteraksi sosial khususnya mahasiswa baru tahun 2020 dalam dunia perkuliahannya. Mahasiswa yang baru memasuki dunia perkuliahan mau tak mau harus beradaptasi selama perkuliahannya di tengah pandemi Covid-19 yang masih terasa asing baginya. Tak sedikit mahasiswa baru banyak yang cemas dan bingung tentang apa yang harus dilakukannya dan bertanya kepada siapa tentang apa yang tidak diketahuinya. Bertahan dan yakin untuk bisa melaluinya, kita disuguhi oleh pembelajaran dalam pernyataan bahwa pilihan untuk bertahan dan mencoba menerima keadaan adalah membangun persepsi positif untuk diri sendiri. Membangun kepercayaan diri, bahwa semua kejadian ada masanya [1].

Transisi memasuki dunia perkuliahan dari Sekolah Menegah Atas atau SMA meskipun adalah hal yang normatif yang dialami semua mahasiswa baru. Namun, transisi tersebut juga dapat menimbulkan stress karena transisi terjadi secara bersamaan dengan perubahan lain, baik dalam diri individu, di dalam keluarga, maupun di perkuliahan. Salah satu bentuk adaptasi terkait dengan perubahanperubahan yang dialami mahasiswa baru adalah penyesuaian diri. Scheiders (dalam
Rohmah, 2004) berpendapat bahwa penyesuaian diri adalah proses kecakapan mental dan tingkah laku seseorang dalam menghadapi tuntutan-tuntutan baik dari dalam diri sendiri maupun lingkungannya [2].

Mahasiswa baru saat ini sedang berada pada fase perkembangan dewasa awal. Masing-masing tahap perkembangan memiliki karakteristik, tugas serta tuntutan yang harus dipenuhi oleh individu. Pada masa dewasa awal ini (Hurlock, 1980) adalah tahap pencarian yang penuh dengan masalah, ketegangan emosional, periode isolasi sosial, serta perubahan nilai-nilai dan penyesuaian diri pada pola hidup [3].

Kesulitan dalam penyesuaian diri menimbulkan culture shock pada mahasiwa baru. Culture Shock adalah kondisi seseorang merasa takut dan khawatir yang berlebihan ketika berada di lingkungan baru yang tidak terbiasa oleh dirinya. Kegelisahan dan rasa takut yang muncul dari hilangnya simbol kefamiliaran akibat perbedaan nilai kebudayaan baru yang belum terbiasa bagi dirinya. Keterkejutan mahasiswa baru ketika dihadapkan oleh sesuatu yang baru baginya dan mendorong mahasiswa baru untuk meninggalkan kebiasaan lamanya. 
Culture Shock dalam istilah psikologis menggambarkan perasaan yang muncul ketika seseorang tengah dihadapkan oleh kondisi lingkungan sosial baru yang berbeda dari diri lamanya. Perasaan yang muncul meliputi perasaan tidak berdaya, rasa takut, gelisah, menarik diri dari lingkungan sosial maupun keluarga, merendahkan diri, merasa diri tak berharga dan ketidakmampuan mengatasi tututan lingkungan, sehingga hal tersebut bisa mempengaruhi pola kehidupan individu. Seperti gangguan pola makan, gangguan tidur, sulit berkonsentrasi, menyendiri, dan mengalami stress yang berkepanjangan.

Seseorang yang menderita stress, biasanya terlihat pada ketidakmampuannya untuk menyesuaikan diri dengan lingkungannya, mengalami gangguan kecemasan, depresi dan gangguan psikosomatik. Stress yang terjadi selama proses pendidikan biasa disebut stress akademik. Stress akademik adalah stress yang bersumber dari proses belajar mengajar atau berhubungan dengan kegiatan belajar, seperti tekanan untuk lulus mata kuliah, lama belajar, banyak tugas, kecemasan ujian, dan manajemen waktu (Demita, 2011: 297-298). Sehingga mahasiswa terlihat murung, kehilangan selera humor, sulit tidur, sakit kepala, dan menurunnya imun tubuh [4]
Culture Shock yang dialami mahasiswa baru selama perkuliahan daring dimunculkan akibat perasaaan khawatir tentang dunia perkuliahan barunya. Terputusnya interaksi sosial secara tatap muka yang beralih menjadi serba online membuat mahasiswa memperkirakan dan berekspektasi sendiri tentang apa yang terjadi pada lingkungan sosial dan keadaan pada dirinya sendiri. Ekspektasi yang dimunculkan mahasiswa baru menjadi berlebihan hingga mengukur keadaan dirinya ke keadaan yang sebenarnya belum terjadi. Memprediksikan sesuatu dan overthingking yang berlebihan memicu tekanan psikologis seperti stress dan gangguan lainnya pada pola kehidupannya.

\section{METODE PENELITIAN}

Artikel penelitian ini bertujuan untuk mendeskripsikan masalah psikologis yang terjadi pada mahasiswa baru akibat cuture shock selama perkuliahan daring. Penelitian ini menggunakan metode kajian literatur dan metode introspeksi diri oleh penulis. Penelitian ini diangkat dari gejala-gejala dan permasalahan psikologis yang dialami sendiri oleh penulis bersama pengamatan penulis terhadap apa yang dialami oleh lingkungan perkuliahan di sekitar 
penulis. Sehingga penulis dapat menemukan permasalahan yang ada, menghubungkannya, dan mengintrospeksikannya pada diri penulis sendiri. Penelitian dilakukan pada tanggal 18 November 2020.

\section{HASIL DAN PEMBAHASAN}

Culture Shock sebenarnya sering kita jumpai dan kita alami dikehidupan kita sehari-hari, entah itu saat kita memasuki jenjang sekolah ataupun perguruan tinggi, berada di wilayah asing yang berbeda budaya dan bahasa, maupun dalam pergaulan lingkungan sosial. Reaksi psikologis dari culture shock umumnya berupa perasaan gelisah, khawatir, takut, upaya menarik diri, dan merendahkan dirinya sendiri. Culture shock pada mahasiswa baru memunculkan tekanan psikologis selama perkuliahan daring. Culture Shock yang dialami mahasiswa baru selama perkuliahan daring meliputi,

1. Menarik diri dari pergaulan sosial

Sulitnya mahasiswa baru dalam beradaptasi menerima keadaan dirinya sendiri yang tibatiba harus berubah mengikuti arus kehidupan barunya. Meninggalkan ritme kehidupan seperti biasanya di zona nyaman yang beralih ke perubahan baru. Mahasiswa baru cenderung akan merasa tertekan, gelisah, takut, overthingking, hingga menarik diri dari pergaulan sosialnya. Menarik diri dari pergaulan sosial ditujukan untuk memberi jarak atas pola pergaulan dan perubahan hidup yang masih terasa asing pada dirinya. Upaya pertahanan diri untuk menghindari kejutan-kejutan lain yang mampu melemahkan diri, sehingga membatasi diri dari pergaulan sosial untuk memberi ruang napas bagi mahasiswa baru untuk mulai menerima, menyeleksi, dan beradaptasi secara berlahan.

2. Merasa ditolak

Mahasiswa baru yang mengalami culture shock akan merasa ditolak oleh kehidupan perkuliahan. Perasaan ditolak muncul ketika diri individu tersebut secara psikologis merasa tidak memenuhi kriteria untuk menjalani kehidupan perkuliahan. Kehidupan perkuliahan yang dipandangnya dipenuhi oleh mahasiswa yang sempurna dan memenuhi kriteria, sangat berbeda dengan apa yang ada dalam dirinya. Perkuliahan secara daring ini, melakukan proses pembelajaran yang dibatasi oleh 
layar. Apa yang terlihat oleh layar itu sebagai image individu. Upaya pelukisan kesempuraan image individu di depan layar sebagai bentuk penjagaan citra diri. Seringkali, mahasiswa baru yang mengalami culture shock ini melihat image yang terlihat pada mahasiswa lainnya di layar sebagai image sempurna yang jauh dari dirinya yang banyak kekurangan.

Interaksi yang dibatasi oleh layar inilah menjadikan timbulnya insecure pada sebagian mahasiswa yang mengalami culture shock. Insecure dalam artian membandingbandingkan dirinya dengan orang lain, berekspektasi tinggi, dan merasa rendah diri. Dari merasa rendah diri inilah, ia merasa di tolak oleh lingkungannya karena jauh dari standar kriteria. Adywibowo (2010) anak yang memiliki kepercayaan diri rendah akan memiliki sikap dan perilaku antara lain: enggan mencoba hal baru, merasa tidak dicintai dan diinginkan, cenderung melempar kesalahan pada orang lain, memiliki emosi yang tersembunyi, mudah mengalami frustasi dan tertekan meremehkan bakat dan kemampuannya dirinya sendiri serta mudah terpengaruh orang lain.
Kepercayaan diri pada mahasiswa baru perlu dibangun kembali agar tidak mudah menyalahkan dirinya dan keadaananya pada setiap masalah. Kepercayaan diri adalah keyakinan seseorang akan kemampuan yang dimilikinya untuk menampilkan perilaku tertentu atau mencapai target tertentu. Rasa percaya diri akan membuat mahasiswa baru mampu mengatasi tekanan dan penolakan dari lingkungan sosialnya. [5]

3. Homesick

Bagi sebagian mahasiswa perantauan tentunya akan menjadi rindu akan rumah dan kampung halamannya. Homesick tidak hanya diartikan sebagai seseorang itu rindu akan kampung halamannya saja atau tempat seseorang itu berasal. Homesick bisa berupa kerinduan akan keadaan dirinya yang dahulu, suasana diri lama yang telah tinggalkan, kerabat, dan keluarga yang ditinggalkan. Menjalani kehidupan yang tidak lagi sama seperti dahulu, membuat kita harus dan harus bisa menjalani kehidupan secara mandiri dan mengandalkan diri sendiri. 
Perbedaan yang menjadi

salah satu hambatan dan tantangan

bagi mahasiswa baru yang merantau adalah kesulitan berkomunikasi karena bahasa yang berbeda, perbedaan makanan, budaya, dan perbedaan moral etika. Desmita (2009) mengatakan bahwa ketidakmampuan menyesuaikan diri mengakibatkan individu mengalami perasaan rendah diri, tertutup, suka menyendiri, kurang percaya diri serta malu jika berada diantara orang lain atau situasi yang terasa asing baginya [6]

Karena itulah peran penyesuaian diri pada mahasiswa baru sangat penting saat memasuki lingkungan baru. Fatimah (2010) mengatakan individu yang tergolong mampu melakukan penyesuaian diri secara positif ditandai dengan tidak menunjukan ketegangan emosional yang berlebihan, tidak menunjukan mekanisme pertahanan yang salah, tidak frustasi, memiliki pertimbangan rasional dalam pengarahan diri, mampu belajar dari pengalaman dan bersikap realistis dan objektif. Individu dikatakan dapat menyesuaikan diri dengan baik apabila mampu melakukan respons yang matang, efisien, memuaskan dan sehat (Schneiders, dalam Ali dan Asrori, 2010)

4. Kehilangan identitas diri dan tujuan hidup

Mahasiswa baru yang mengalami culture shock cenderung menyalahkan dirinya sendiri akan keadaan yang tidak bisa mahasiswa itu kuasai. Mahasiswa akan lupa tentang apa tujuannya berada di dunia perkuliahan dan apapun yang dilakukannya. Mahasiswa juga lupa mengenai kelebihan dan kemampuan potensi yang mahasiswa itu miliki untuk disyukuri dan dikembangkan. Mahasiswa terlalu meragukan dirinya dan merendahkan dirinya sendiri atas segala hal yang dilihatnya di lingkungan yang masih baru ditempatinya ini. Terlalu banyak memikirkan cara menempatkan diri, menyesuaikan diri, dan memenuhi tuntutan lingkungannya dengan baik di lingkungan barunya ini hingga membuatnya lupa akan kepentingan psikologisnya untuk belajar menerima dirinya sendiri, bukan apa yang harus mahasiswa lakukan kepada lingkungan barunya. 
5. Kejutan perubahan dan kebiasaan

Perkuliahan secara daring selama pandemi Covid-19 tentunya membawa perubahan pada proses pendidikan di Indonesia. Proses belajar kini beralih via online menggunakan aplikasi zoom meet atau aplikasi pendukung lainnya. Di zaman sekarang media sosial dan penguasaan elektronik terus berkembang dan semakin maju. Proses pembelajaran daring selama perkuliahan adalah hal yang baru bagi mahasiswa baru namun, mahasiswa baru masih dapat mengikuti transformasi online ini.

Di awal perkuliahan, mahasiswa baru tentu sangat sibuk dalam mencari informasi tentang dunia perkuliahan barunya lewat media internet. Gadget harus selalu sedia agar tidak ketinggalan informasi, baik itu informasi tentang perkuliahan maupun diskusi saling mengenalkan diri. Karena semasa perkuliahan daring, media chat online sangat diperlukan untuk menjalin komunikasi antar mahasiswa. Hal itu membuat mahasiswa menjadi keseringan memegang gadget yang awalnya memegang gadget selama 4-5 jam perhari menjadi lebih dari 7 jam perhari.
Perkembangan internet sangat mempengaruhi kehidupan sosial serta cara berkomunikasi seseorang. Culture shock pada cara berkomunikasi dalam media chat online juga menjadi salah satunya. Interaksi media online yang meninggalkan norma etikanya ketika proses komunikasi sedang berlangsung. Mengindahkan bagaimana kondisi seseorang yang diajak berbicara dengan asal mengutarakan keinginan melalui kata-kata yang sepihak. Pengelolaan kata-kata yang salah menimbulkan persepsi yang berbeda dan mentransfer energi negatif pada individu atau kelompok yang diajak berbicara.

Pengelolaan kesan adalah bagian dari keinginan sosial yang dilakukan secara sadar maupun tidak sadar sebagai usaha mengontrol citra diri agar diterima oleh orang lain (Mtshelwane dkk, 2016). Kebutuhan afiliasi dalam menjalin huubungan yang baik dan hangat dengan orang lain sangat diperlukan (McClelland, 1987). Maka dari itu perlulah kita menjaga dan mengontrol diri saat melakukan percakapan dengan orang lain di media sosial. Berdasarkan penelitian Kordik, Eska \& 
Schultheiss (2012) menyatakan bahwa kebutuhan afiliasi dapat menentukan perasaan nyaman dari individu lain, kontak yang harmonis, dan mengetahui ketidaksenangan saat menolak motif pertemanan [7].

\section{Sulit konsentrasi}

Salah satu dampak dari perkuliahan daring adalah sulitnya mahasiswa baru dalam berkonsentrasi pada pelajarannya. Perkuliahan daring melalui zoom meet membuat mahasiswa menjadi kesulitan menangkap informasi yang disampaikan dosen selama perkuliahan. Kehilangan fokus mahasiswa serta mata yang lelah menatap layar laptop dalam jangka panjang. Kesulitan mengingat menjadi salah satu hambatan yang merugikan bagi mahasiswa. Masalah belajar tidak dapat terlepas dari masalah memory (daya ingat), karena konsep dari belajar dan memori memiliki hubungan yang berkaitan erat, dan hasil belajar haruslah dapat disimpan dan dipelihara dalam memori agar dapat digunakan [8].

Sistem memori manusia dapat dijelaskan oleh model paradigma Atkinson dan Shiffrin yang telah disempurnakan oleh Tulving dan Madigan (Solso, 1991). Dalam model ini terdapat tiga sistem penyimpanan, yaitu register sensori, memori jangka pendek, dan memori jangka panjang. Informasi yang diterima dan disimpan dalam ingatan jangka pendek sangat rapuh, dan apabila informasi ini tidak diulang dalam jangka waktu 30 detik, maka informasi yang telah diterima akan hilang (Reed, 2007). Informasi yang kita perdapat menjadi pengetahuan di ranah otak. Manakala pikiran bekerja, maka pengetahuan di otak akan menjadi pengetahuan baru, bisa pula dipakai istilah "ciptaan" sebagai keluaran dari hal-hal yang sudah ada (di memori) menjadi hal baru. pikiran penggodok pengetahuan baru [9]. Karena itulah kefokusan konsentrasi selama perkuliahan apalagi dalam pembelajaran daring sangat diperlukan agar mahasiswa dapat memaksimalkan proses pembelajarannya untuk mencapai pengetahuan dengan baik.

Dapat kita amati bahwa pengaruh perkuliahan daring pada mahasiswa baru memunculkan gejala cuture shock yang dapat mengganggu proses 
perkuliahan maupun kehidupan

mahasiswa. Perubahan pola kehidupan dan kebiasaan mulai berubah mengikuti alur dunia perkuliahan, walaupun pada prosesnya dilalui oleh pertentangan kebiasaan individu pribadi pada awalnya.

Culture shock yang dialami mahasiswa baru selama memasuki dunia perkuliahan yang baru dan proses pendidikan baru secara daring membuat masalah tersendiri pada psikologis mahasiswa baru. Akan tetapi, dari penyesuaian adaptasi mahasiswa baru terhadap culture shock selama perkuliahan daring mengajarkan mahasiswa untuk berlatih membuka diri terhadap perkuliahan barunya.

Mencoba bersikap lebih dewasa dalam pola pikir, melatih diri untuk terbuka dan mampu menyesuaikan diri terhadap perubahan yang terjadi sepanjang hidupnya. Mengubah segala ketidakpercayaan pada diri sendiri menjadi motivasi untuk bergerak lebih maju. Refleksikan diri dan berbenah serta fokus pada tujuan yang dibuat. Memaafkan diri dan mensyukuri segala yang ada dalam diri sendiri. Seligman (2002) menyatakan bahwa rasa syukur ialah suatu bentuk emosi positif dalam mengekspresikan kebahagiaan dan rasa terima kasih individu terhadap segala kebaikan yang diterimanya. Perasaaan psikologis yang memberikan penghargaan terhadap kehidupan, sehingga mahasiswa mampu melihat kehidupannya sebagai sesuatu yang berharga dan patut disyukuri [10].

Mereflesksikan diri dan menerima kenyataan bahwa semua itu sebagai jalan menuju perubahan yang baik pada diri kita. Menyeimbangkan perspektif untuk berpikir positif dan mendekatkan diri pada nilai spritualitas untuk membawa diri lebih mensyukuri kehidupan. Zohar dan Marshal mengartikan kecerdasan spritual sebagai kecerdasan untuk menghadapi persoalan makna dan nilai untuk menempatkan perilaku dan hidup dalam konteks yang luas. Kecerdasan spiritual adalah landasan yang diperlukan untuk memfungsikan IQ dan EQ secara efektif. Sehingga mahasiswa akan mampu memaknai dan menilai tindakan yang dilakukan olehnya sendiri [11].

Mendekatkan diri pada hubungan spiritual kepada Tuhan, menurut Agustian akan mendorong terbentuknya empat sikap positif diantaranya adalah integritas atau kejujuran, energi atau semangat, wisdom atau kebijaksanaan, dan keberanian mengambil keputusan (Haryono \& Rosady, 2017). Dengan 
begitu culture shock akan mampu diatasi oleh masing-masing individu dan berjalan bersama perubahan diri dengan hati yang lapang.

\section{KESIMPULAN}

Diperlukan motivasi serta dukungan psikologis agar mahasiswa mampu menjalani kehidupan perkuliahan dengan penuh semangat. Peran lingkungan keluarga sangat membantu mahasiswa baru yang

\section{REFERENSI}

[1] Abbas, E. W., \& Erlyani, N. (2020). Menulis di Kala Badai Covid-19.

[2] Azhari, M. A. S., Mayangsari, M. D., \& Erlyani, N. (2016). Hubungan Perilaku Asertif dengan Penyesuaian Diri pada Siswa Tahun Pertama di SMP. Jurnal Ecopsy, 2(1).

[3] Afnan, A., Fauzia, R., \& Tanau, M. U. (2020). HUBUNGAN EFIKASI DIRI DENGAN STRESS PADA MAHASISWA YANG BERADA DALAM FASE QUARTER LIFE CRISIS. Jurnal Kognisia: Jurnal Mahasiswa Psikologi Online, 3(1), 23-29.

[4] Afnan, A., Fauzia, R., \& Tanau, M. U. (2020). HUBUNGAN EFIKASI DIRI DENGAN STRESS PADA MAHASISWA YANG BERADA DALAM FASE QUARTER LIFE CRISIS. Jurnal Kognisia: Jurnal Mahasiswa Psikologi Online, 3(1), 23-29. mengalami culture shock agar mahasiswa merasa berharga dan merasa masih banyak orang yang peduli padanya. memperbaiki pola dalam berpikir juga menjadi alasan pada mahasiswa baru dalam merepons segala hal yang terjadi dalam kehidupannya. Siap menerima perubahan dan mensyukuri apa yang terjadi menjadi salah satu kunci dalam kehidupan yang bahagia sebagai seorang mahasiswa.
[5] Siregar, A. O. A., \& Kustanti, E. R. (2020). Hubungan antara gegar budaya dengan penyesuaian diri pada mahasiswa bersuku minang di universitas Diponegoro. Empati, 7(2), 474-490.

[6] Helmiyyah, S., Erlyani, N., \& Mayangsari, M. D. (2020). HUBUNGAN RASA SYUKUR DENGAN ALTRUISME PADA MASYARAKAT YANG TINGGAL DI WILAYAH TAMBANG BATUBARA ASAMASAM. Kognisia prodi Psikologi FK ULM, 2(2), 140-148.

[7] Rizky, L., Erlyani, N., \& Akbar, S. N. (2020). HUBUNGAN ANTARA KEBUTUHAN AFILIASI DENGAN PENGELOLAAN KESAN PADA REMAJA PENGGUNA MEDIA SOSIAL INSTAGRAM DI SMA NEGERI 2 
BANJARBARU. Kognisia prodi Psikologi FK ULM, 1(1), 68-75.

[8] Zwagery, R. V., \& Dewi, R. S. PENGARUH KEBISINGAN TERHADAP DAYA INGAT PADA REMAJA.

[9] WARMANSYAH ABBAS, E. R. S. I. S. (2015). Menulis Ala Ersis Writing Theory.

[10] Cimi, A., Erlyani, N., \& Rahmayanti, D. (2016). Pola Asuh Orang Tua Dengan Kepercayaan Diri Anak. Dunia Keperawatan: Jurnal Keperawatan dan Kesehatan, 1(1), 5763.

[11] Febriani, N., Istiqomah, E., \& Tanau, M. U. (2020). HUBUNGAN KECERDASAN SPIRITUAL DENGAN PERILAKU PROLINGKUNGAN PADA KARYAWAN QHSE PT.
ADARO INDONESIA. Jurnal Kognisia: Jurnal Mahasiswa Psikologi Online, 3(1), 51-61.

Ward, C. A., Bochner, S., \& Furnham, A. (2001). The psychology of culture shock. Psychology Press.

Niam, E. K. (2009). Koping terhadap stres pada mahasiswa luar jawa yang mengalami culture shock di Universitas Muhammadiyah Surakarta.

Riadi, S., Normelani, E. N., Efendi, M., Safitri, I., \& Tsabita, G. F. I. (2020). Persepsi Mahasiswa Prodi S1 Geografi FISIP ULM Terhadap Kuliah Online Di Masa Pandemi Covid-19. PADARINGAN (Jurnal Pendidikan Sosiologi Antropologi), 2(2), 219-227. 